$12-31-2019$

\title{
Applying positive language in mindful parenting: A means of building positive character in children
}

\author{
Amrina Rosyada \\ English Education Program, Faculty of Language and Arts, Indraprasta PGRI University, Indonesia, \\ 4mrin4@gmail.com \\ Agustina Ramadhianti \\ English Education Program, Faculty of Language and Arts, Indraprasta PGRI University, Indonesia, \\ agustinaramadhianti79@gmail.com
}

Follow this and additional works at: https://scholarhub.ui.ac.id/ajce

Part of the Education Commons

\section{Recommended Citation}

Rosyada, Amrina and Ramadhianti, Agustina (2019). Applying positive language in mindful parenting: A means of building positive character in children. ASEAN Journal of Community Engagement, 3(2). Available at: https://doi.org/10.7454/ajce.v3i2.1058

Creative Commons License c) (i) (2)

This work is licensed under a Creative Commons Attribution-Share Alike 4.0 License.

This Research Article is brought to you for free and open access by the Universitas Indonesia at ASEAN Journal of Community Engagement. It has been accepted for inclusion in ASEAN Journal of Community Engagement. 


\title{
Applying positive language in mindful parenting: A means of building positive character in children
}

\author{
Amrina Rosyada $\mathrm{a}^{*}$, Agustina Ramadhiantia \\ ${ }^{a}$ English Education Program, Faculty of Language and Arts, Indraprasta PGRI University, Indonesia
}

Received: July 13 ${ }^{\text {th }}, 2019$ || Revised: August $2^{\text {nd }}$, September 17th, December $1^{\text {st }}, 2019$ || Accepted: December $10^{\text {th }}, 2019$

\begin{abstract}
Positive language is a crucial communication tool, both within the family environment and in external circumstances. Previous research endeavors have evidenced that the inculcation of positive language by parents is effective in building positive character in their children. Thus, language is not merely a communication tool; it is also a means of personality development. However, this application cannot be realized if parents are unaware. Therefore, the community service activity proposed in this paper aims to broaden and strengthen mindful parenting, and to enhance the discernment of positive language in parents to help them build positive character in their children. To this end, a community-based research process was applied through activities held in a community center to mentor and assist 30 young Muslim couples whom were married for a period of 5 to 20 years. An expert psychologist was engaged to help the participating couples comprehend two perspectives of mindful parenting: language education and psychology. A mini handbook for the application of positive language was distributed to each participating couple as guidance to enable them to continuously employ mindful parenting with their children. This community service activity expanded and reinforced the commitment of all participants to work together to inculcate their children with positive personalities. Parents must be mindful of every single word they say and everything they do if they desire to build a better future generation. The more parents apply positive language in mindful parenting, the more children will be assimilated with constructive personalities.
\end{abstract}

Keywords: positive language, mindful parenting, positive character, community-based research, language education

\section{Introduction}

The development of positive personalities in children has become a crucial issue together with the development of advanced information and technology in recent years. This concern should be shared by all components of civil society, particularly families. According to Rahmatullah (2017), today's children are caught in the digital trap that causes them to become spoiled and pampered by technological prowess where anything that is highly technological is deemed sophisticated. It is stated that the children are easily trapped due to the "split personality" syndrome that occurs in the parents and their children in which the parental role is taken by digital media in the absence of 
healthy parent-child relationships and attachments, where communication between parents and children are scarce.

Children are nurtured, formed, grow up, and are most influenced by the family environment. However, the family unit, which is the closest emotional tether for a child, is challenged and disrupted in the present environment. It is widely accepted that the involvement of parents is associated with improved educational outcomes in children (Daniel, Wang, \& Berthelsen, 2016). Unfortunately, most families do not have enough knowledge or information about how to deal with the rapidly changing environmental circumstances. Additionally, most couples are not sufficiently prepared to become parents of children for whom they must take full responsibility in the family environment and for whom they must become role models. Parents seem to lose their vision and mission of inculcating appropriate principles and values in their children as the future generation who will inherit the world. Instead, parents appear to let their children grow up in response to the demands of fast-changing circumstances in which sophisticated information and technology have taken away the parental role of inculcating family education. Thus, parents allow children to lose their family-based identity and values that form their essential characters. This situation should not happen since several studies have proved the negative effects of the use of advanced electronics in early childhood (Parish-Morris, Mahajan, Hirsh-Pasek, Golinkoff, \& Collins, 2013).

To negotiate the effects of the disruptions caused by the advances in information and technology, several research initiatives have examined ways to find the appropriate solutions to this contemporary problem. One such answer is mindful parenting. An evaluation was conducted in 2010 to assess the efficacy of mindful parenting programs in changing the state of alertness in parents, in altering child management practices, and in ameliorating relationships with early adolescent children. The findings revealed that family risk can be mitigated and protection during a child's transition into adolescence can be enhanced by infusing mindful parenting activities into existing empirically validated parenting programs (Coatsworth, Duncan, Greenberg, \& Nix, 2010).

A recent study on mindful parenting conducted in 2016 defined mindful parenting as a set of parental practices or skills that seek to enhance moment-to-moment awareness in the parent-child relationship. This study engaged the participation of 333 parents and utilized several parenting styles. The results revealed that higher levels of dispositional 
mindfulness and self-compassion are associated with higher levels of mindful parenting which, in turn, is associated with lower levels of parenting stress, higher levels of authoritative parenting, and lower levels of authoritarian and permissive parenting styles (Gouveia, Carona, Canavarro, \& Moreira, 2016).

In the same year, another study on parenting styles focused on family communication and examined the use of positive language as an important tool for building positive characters in children. Several interventions of community-based research activities on positive language were utilized to socialize and mentor parents. The study scrutinized the positive language used by 118 participating mothers to build positive behavior in their children. The results of this investigation evinced that only $26.27 \%$ of the participants implemented positive language within their family environment. Most mothers found it very difficult to implement the learnings about positive language because they had to discharge several responsibilities including schooling-related issues, household chores, financial duties, and so on. Mothers appeared to perform all the child-related responsibilities on their own without any effective support from other family members, particularly from their husbands. Therefore, further research is needed to engage fathers in encouraging the use of positive language in family environment (Rosyada \& Retnomurti, 2017).

Such imperfect circumstances often appear to cause a high risk of depression in mothers, which also triggers depressive tendencies in other family members, mostly children. Several previous investigations (Ball, 2010; Seals, 2018) have discovered that family circumstances affect the identity development of children and influence a child's ability to negotiate its present and future environments. Hence, mothers and fathers must take equal responsibility for their children and must collaborate to undertake the family education of their children, particularly in the task of developing positive characteristics in their progeny. Early childhood care and development programs are essential for the successful engagement of children in the subsequent stages of formal education.

Other research projects (Lexmond \& Reeves, 2009) have also proved that parents are the primary character builders in a society. The level of warmth, responsiveness, control and discipline in the parental approach to children exert a major influence on the character and capability development of children. Since recent social and economic 
changes have placed a premium on personality and ability, these aspects are even more crucial to success. Thus, children must be accorded an early and fair beginning.

In congruence with the above conditions and previous research endeavors, the community service activity posited in the present paper focused on increasing the involvement of parents in using positive language through mindful parenting to develop positive personalities in their children. The community-based research activities organized in the Muslim community center of Baitul Hasan Jagakarsa purposed to 1) remind parents of their responsibilities relating to the home education of their children; 2) enhance the comprehension of fathers about their roles in the home education of their children; 3) advise and demonstrate the utilization of positive language and mindful parenting; and 4) to assist in the implementation of positive language and mindful parenting. A remarkable output of positive characteristics in children can be attained through the implementation of these four purposes pertaining to positive language (Nix, Bierman, Domitrovich, \& Gill, 2013). Fathers and mother's involvement positively contributed to children's cognitive and social emotional development. Fathers and mothers who participated in more frequent home literacy involvement, such as shared book reading, had children with better reading, math, and social emotional outcomes in preschool (Baker, 2013).

\section{Methods}

The activity that forms the subject of the present paper was conducted in the Muslim community center of Baitul Hasan Jagakarsa, located in Jln. Moch. Kahfi II No. 44 RT 002 RW 001 Kelurahan Jagakarsa, Kecamatan Jagakarsa, Jakarta Selatan, DKI Jakarta. The community center's membership ranges from children under 5 years old to the elderly aged above 60 and their numbers exceed 500 people living in four sub-districts: Lenteng Agung, Jagakarsa, Srengseng Sawah, and Ciganjur. All members of the community center engage in weekly activities to receive the learnings of $\mathrm{Al}$ Quran and Al Hadith. In addition, a special monthly forum is held for mothers on the latest Sunday of the month. This special monthly forum conducts several discussion forums related to education, parenting programs, family health care, older adult care, and other crucial issues. The issues encourage the community members in all level of age to join and to participate in such interesting issues. 
The community service activity undertaken for this study involved 30 couples who were married for a period of 5 to 20 years. Most of the participants were parents, and only one couple did not yet have any children. Most of the mothers were homemakers, but several were also teachers or were employed in other positions. Most of the fathers worked in private enterprises; however, a few of them were government employees.

The entire study was accomplished in five months, between February and June 2019. The community-based research program (Lang et al., 2012) also engaged two members of the community center where the activities were held: an expert psychologist and a mubaligh belonging to the community. The mubaligh, who was involved in the research project is also a $6^{\text {th }}$ semester student of a consulting program at Indraprasta PGRI University and stood for the psychologist assistant.

The interactive program encompassed the administration of two types of questionnaires as the research instruments: one for parents, and one for children. The questionnaire for parents collected information pertaining to the couples' knowledge of positive language, positive parenting, and mindful parenting. The questionnaire for children gathered data on the parental application of appropriate behavioral education related to a positive home environment. Each questionnaire comprised 20 statements and was scored on a scale of 1 to 3 . In this manner, two scoring perspectives were obtained: the participants' answers yielded a minimum score of 20 and a maximum score of 60; the questionnaire items computed a base score of 30 and the uppermost score of 90 . The instruments were distributed to the participants who were asked to fill in their responses before the presentation session.

The study was conducted in four phases: 1) foundational exercises; 2) planning; 3) information gathering and analysis; and 4) acting on the findings (Ochocka \& Janzen, 2015). The detailed descriptions of the four phases follow.

\subsection{Laying the foundations.}

During the first phase, the research team discussed goals and roles and accomplished tasks such as role clarification, the organization of stakeholders, and the institution of steering groups. Further, the research assumptions were identified also defined at this foundational stage: contextual circumstances were highlighted, and the purpose of the study was elucidated. 


\subsection{Planning}

The second phase comprised discussions of perspectives from which to clarify the research questions, the development of methods to collect data, and the formation of an analysis plan. Technically, the team collected adequate information about the needs of the concerned community and prepared the requisite research material based on the team's experiences and relevant extant literature. Several schedules were established, and sundry other arrangements were made with the expert psychologist and the assistant engaged from the community for the purposes of the present study.

\subsection{Information gathering and analysis.}

In this phase, the team arrived at a consensus on the definitions, means, and learning about the collection, analysis, and interpretation of obtained information. The engagement of all participants was encouraged, and they were asked to share their knowledge and experiences with other members to afford discrete insights to the group. A focus group discussion (FGD) was conducted. In the FGD, there were 3 sessions of activities including opening session and completing questionnaires, presentation and small group discussion session, and summarizing and closing session. Further, all the information was gathered and analyzed by the team.

\subsection{Acting on findings.}

The research team summarized and documented all the obtained information based on the data analysis and interpretation and formulated a mini handbook of guidelines, which was distributed to each participant of the study.

\section{Result and Discussion}

The FGD was conducted on March 7, 2019. The information collection activity was divided into three sessions: opening session and completing questionnaires, presentation and small group discussion session, and summarizing and closing session. All participants attended an interactive presentation session where the material relevant to mindful parenting was introduced to them. They could interrupt the presenter and were encouraged to ask questions on the material. The presentation encompassed two perspectives: psychology and language education perspectives. The 
psychology aspect covered the challenges posed by the current digital era that affects the children's behavior and personalities and offered solutions to potential difficulties. The language education standpoint included information on parenting styles, positive parenting, mindful parenting, positive language, and positive personality.

After the presentation, the participants were grouped into several small units of 3 to 5 couples to discuss and to share their understanding and experiences of the role of positive language in positive and mindful parenting. Each group selected a leader who would lead the group discussion and would present the summary of the group discussion. This session was facilitated by the research team. In the final segment, each group presented the summary of its discussions and the research team collated the summaries and derived several key points that emerged from the full forum. In the closing session, the research team presented its conclusions and offered several suggestions to the participants.

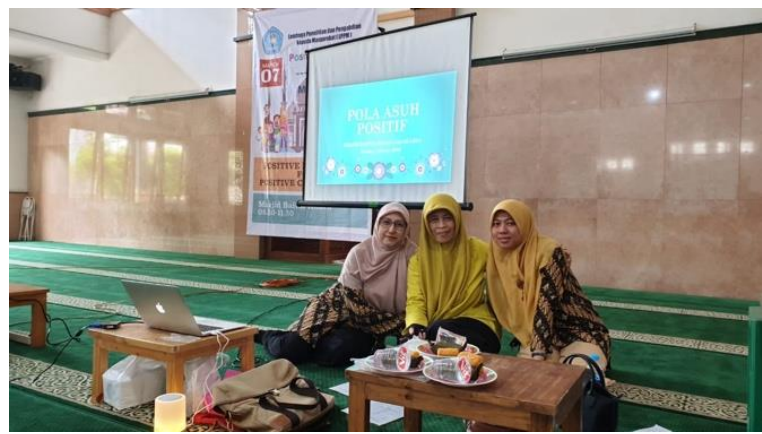

Fg. 1 FGD Speakers

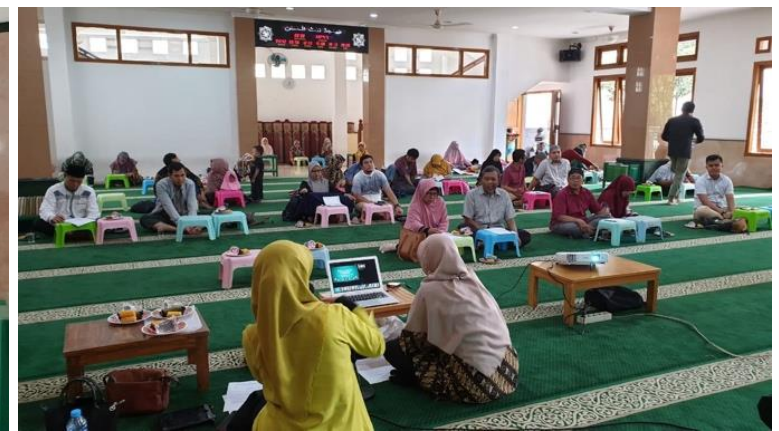

Fg. 2 FGD Forum

Source: Author (2019)

Before the presentation session, the participating couples were assisted in the filling in of the questionnaires querying their knowledge and application of positive language, positive character, and mindful parenting. Each questionnaire comprised 20 statements that yielded a minimum score of 20 and a maximum score of 60 . The data obtained from the participant responses to the questionnaire items are presented in the tables that follow. Table 1 displays the scores based on answers provided by each participating couple, both for items that ascertained knowledge and those that were designed to determine the participants' implementation of the abovementioned factors of positive language, positive character, and mindful parenting. In this filling in the questionnaires, each participating couple of husband and wife, could discuss and decide the best 
182

Amrina Rosyada, Agustina Ramadhianti | ASEAN Journal of Community Engagement | Volume 3, Number 2, 2019

answers for the questionnaires. Each number in the column of participants represents one participating couple.

Table 1. Result Data of Each Participant's Answers

\begin{tabular}{llllll}
\hline Participants & $\begin{array}{l}\text { Parents' } \\
\text { Knowledge }\end{array}$ & $\begin{array}{l}\text { Parents' } \\
\text { Implementation }\end{array}$ & $\begin{array}{l}\text { Participants } \\
\text { Parents' } \\
\text { Knowledge }\end{array}$ & $\begin{array}{l}\text { Parents' } \\
\text { Implementation }\end{array}$ \\
\hline 1 & 54 & 50 & 16 & 50 & 49 \\
2 & 58 & 42 & 17 & 55 & 48 \\
3 & 53 & 47 & 18 & 52 & 46 \\
4 & 54 & 54 & 19 & 59 & 48 \\
5 & 58 & 51 & 20 & 47 & 57 \\
6 & 56 & 53 & 21 & 52 & 50 \\
7 & 60 & 46 & 22 & 52 & 51 \\
8 & 60 & 49 & 23 & 54 & 48 \\
9 & 58 & 51 & 24 & 54 & 39 \\
10 & 54 & 52 & 25 & 60 & 47 \\
11 & 53 & 43 & 26 & 53 & 49 \\
12 & 57 & 34 & 27 & 59 & 51 \\
13 & 60 & 0 & 28 & 56 & 47 \\
14 & 20 & 0 & 29 & 53 & 0 \\
15 & 54 & 56 & 30 & 55 & 44 \\
\hline
\end{tabular}

Source: Author (2019)

Table 1 is based on the answers recorded by 30 participating couples to the questionnaires. The data pertaining to the participants' knowledge of positive language, positive parenting, and mindful parenting registered a minimum score of 20 for one young couple and the maximum score of 60 for four couples. The minimum score was recorded by a very young couple. This set of very young parents had just been blessed with a baby girl and thus had very limited knowledge of positive language, positive 
parenting, and mindful parenting. The data regarding the participants' implementation of a positive home environment for their children evinced a minimum score of 0 for three couples and the maximum score of 57 for one couple. The response descriptions elucidated that the three couples who scored 0 comprised two sets of parents of newborn babies and a couple without children. Thus, these three couples were not accorded the opportunities of applying their knowledge of positive language, positive parenting, and mindful parenting.

Table 2. Result Data of Each Statement on the Questionnaires

\begin{tabular}{|c|c|c|c|}
\hline $\begin{array}{l}\text { Parents' } \\
\text { Knowledge }\end{array}$ & $\begin{array}{l}\text { Score } \\
(\%)\end{array}$ & $\begin{array}{l}\text { Parents' } \\
\text { Implementation }\end{array}$ & $\begin{array}{l}\text { Score } \\
(\%)\end{array}$ \\
\hline 1 & 86.67 & 1 & 66.67 \\
\hline 2 & 92.22 & 2 & 64.44 \\
\hline 3 & 92.22 & 3 & 68.89 \\
\hline 4 & 100 & 4 & 81.11 \\
\hline 5 & 94.44 & 5 & 82.22 \\
\hline 6 & 90 & 6 & 87.78 \\
\hline 7 & 86.67 & 7 & 82.22 \\
\hline 8 & 87.78 & 8 & 78.89 \\
\hline 9 & 90 & 9 & 54.44 \\
\hline 10 & 90 & 10 & 52.22 \\
\hline 11 & 90 & 11 & 68.89 \\
\hline 12 & 86.67 & 12 & 84.44 \\
\hline 13 & 92.22 & 13 & 72.22 \\
\hline 14 & 86.67 & 14 & 71.11 \\
\hline 15 & 87.78 & 15 & 86.67 \\
\hline 16 & 90 & 16 & 76.67 \\
\hline 17 & 87.78 & 17 & 68.89 \\
\hline
\end{tabular}




\begin{tabular}{llll}
\hline $\begin{array}{l}\text { Parents' } \\
\text { Knowledge }\end{array}$ & $\begin{array}{l}\text { Score } \\
(\%)\end{array}$ & $\begin{array}{l}\text { Parents' } \\
\text { Implementation }\end{array}$ & $\begin{array}{l}\text { Score } \\
(\%)\end{array}$ \\
\hline 18 & 98.89 & 18 & 66.67 \\
19 & 83.33 & 19 & 77.78 \\
20 & 86.67 & 20 & 54.44 \\
\hline
\end{tabular}

Source: Author (2019)

Table 2 consists of 20 statements, each of which expressed principal values to ascertain the knowledge of positive language, positive parenting, and mindful parenting. The 20 items were: 1) knowledge of positive parenting; 2) awareness of positive characteristics; 3 ) both partners sharing the same vision of children's education; 4) both partners being similarly committed to working together to educate their children; 5) teaching the children about the one and only Lord; 6) being positive role models for the children; 7) showing appreciation to children for good and proper conduct; 8) establishing rules with the children; 9) spending play time with the children; 10) taking time to go out with the children; 11) sharing experiences with the children; 12) assigning proportional responsibilities to the children; 13) inculcating some family principles in the children; 14) discussing issues with the children; 15) actively listening to the children; 16) being honest with the children; 17) being aware of the children's changing attitudes; 18) displaying love and affection to the children; 19) not making comparisons between children; and 20) not labelling children with negative terminology. Each item assigned equal weight and was scored, calculated, and presented as a percentage.

The data relating to the knowledge of participating couples reveal the lowest score of $83.33 \%$ for statement number 19 and the highest score of $100 \%$ for statement number 4. According to the scores, around $83.33 \%$ of the participants agreed with item number 19 and stated that every child is unique and thus cannot be compared to another. On the other hand, $16.67 \%$ of the participants either do not know this principle or do not agree with it in their daily parenting. This item is important for it is the basic principle to build children's tolerance in individual differences. When children are brought up in understanding individual differences, children will respect others' differences despite 
bullying (Gini, Pozzoli, \& Hauser, 2011). For children in Indonesia who live in diversity, strengthening the Muslim belief while understanding the differences is a crucial issue.

Meanwhile, all the participating couples or $100 \%$ of the respondents share the value described in item 4 and asserted that both parents were committed to the belief that positive parenting should be implemented at home jointly by the mother and father. Parents believe that raising children together is much helpful for both parents and children. The collaborative roles of father, mother, and children will increase positive relationship between parents and children in one side, and in the other side will decrease depressions on parents and children. By raising children together, parents are eliminating the adverse outcomes of the children for the absence of fathers in the family relationship (Kopala-Sibley et al., 2017; Radl, Salazar, \& Cebolla-Boado, 2017).

Besides the highest score of $100 \%$ for statement number 4 , another high score close to $100 \%$ is statement number 18 . Around $98.89 \%$ of the participants agreed with value number 18 and stated that displaying love and affection to the children is very important. By conveying love and affection to children, parents can manage children's behaviors and misbehaviors. Thus, parental warmth is related to better children adjustment (Lansford et al., 2014). This item is relevant to several items that stated actively listening to the children, being honest with the children, being aware of the children's changing attitudes, not making comparisons between children, and not labelling children with negative terminology. All these values are very important for children in mediating full engagement between parents and children. Through these items, parents build effective communication to children (Benharoon, 2013).

With respect to parental actions to building positive character in their children, there were 20 items of positive language values that measured the children application on positive language. The 20 items were: 1) doing prayers in willingness; 2) doing prayers in time; 3) reciting Al Quran every day; 4) reciting Al Quran and Al Hadith; 5) greeting before enter or exit the home; 6) kissing elder people's hands; 7) saying gratitude when receiving any goods or helps; 8) dare to apologize when doing any mistakes; 9) responsible for cleaning up own bed; 10) responsible for cleaning up own bedroom; 11) responsible for managing private belonging on the right place; 12) putting in any trashes to bin; 13) expressing willingness without crying or yelling; 14) expressing tolerance to others' opinion; 15) playing with friends; 16) repeating lessons every day; 17) completing homework individually; 18) love to reading; 19) love to exercising; and 
20) screen time management. All items were scored equally, calculated and performed as a percentage.

In relevance to the application values that statistically calculated in percentage, the data shows that the lowest score of $52.22 \%$ was recorded for item 10 and the highest score of $87.78 \%$ was registered for item 6 . Thus, $52.22 \%$ of the participants implement item 10 and hold children responsible for cleaning up their own bedrooms; conversely, $47.78 \%$ of the participants do not. This item is related to other values that stated responsible for cleaning up own bed, responsible for managing private belonging on the right place, and putting in any trashes to bin. These three items show the scores over $50 \%$. In this way, the four items express that over $50 \%$ of parents are succeed in promoting children's responsibility at home. Being given some rights, responsibilities, and opportunities will develop understandings of how children enact themselves as part of the social circumstances (Larkins, 2014).

For the highest score of $87.78 \%$ was registered for the implementation of number 6 . This number stated that teach their children to kiss their elders' hands when they enter or exit the home. Only $12.22 \%$ of the participants who do not inculcate the family value of kissing elders' hands in their children. This item is a tradition of Indonesian people in expressing politeness and respect from the younger people to the elder people. In Islam, respecting others especially elder people is related to principle value of Prophet Muhammad SAW stated that, "Respecting elder people, taking care younger people." Children who are accustomed to this value are easily recognized as the Indonesian people, as well as a tradition is preserved as a cultural heritage of Indonesia.

In addition, another high score of $86.67 \%$ was recorded for item 15 that stated playing with friends. This item is relevant to item 19 which stated love to exercising. Both items show that most parents consider the children play with friends and do physical activity with friends. In the disrupted era where the advanced information and technology offers a lot of interesting plays for children has affected physical inactivity. The physical inactivity becomes a key determinant of health across the lifespan. A lack of activity increases several diseases, such as heart disease, colon and breast cancer, diabetes mellitus, hypertension, osteoporosis, anxiety and depression, and many others (IOM (Institute of Medicine), 2013). Therefore, most parents are consciously and continuously aware to support the children to have enough physical activity with their friends. Most of the parents accompany the children to exercising soccer or martial art 
"pencak silat" in every once a week. Some of the parents support the children to join a musical course of violin or piano for once a week.

Moreover, item 20 that stated gadget management registered score of $54.44 \%$. The score expresses that over $50 \%$ of the parents realize to manage the children screen time, whether it is time for television, computer or laptop, and gadget or smartphone. Most parents regularly manage the "tv-off 'movement at 5 pm every day and consider accompanying the children to learn Al Quran and AL Hadith, or to review school homework. Most parents also strictly keep the gadget and smartphone away from the children. The gadget and smartphone time are scheduled on weekend and only for two hours for the maximum utilization. This item implementation has promoted positive atmosphere for children to develop the children's belief and practices of several values, which stated doing prayers in willingness, doing prayers in time, reciting Al Quran every day, and reciting Al Quran and Al Hadith regularly. Equally, this implementation also helps the children to develop school achievement. In this way, parents are able to minimize or even to prevent children from harmful effects of the screen time exposure (Hale \& Guan, 2015; Rosyada \& Ramadhianti, 2019).

In general, all participants expanded their knowledge and insights on positive language, positive parenting, and mindful parenting through the discussion forum and learned how these concepts could be applied within their own family and social environments. All participants shared the spirit and were convinced that the increased implementation of this attained awareness would result in the development of positive qualities in their children. This belief is congruent with a study that found that attributes of early childhood education and care substantially influence later outcomes of individual lives (García-Carrión \& Villardón-Gallego, 2016).

All participants committed to the credence that the implementation of values is not merely the work of mothers; fathers must also support mothers and undertake joint responsibility for the appropriate nurturing of the next generation. The family environment is constructed from maternal psychological control and the emotional expressiveness of the relational unit. The more a family environment emanates positive emotional expressiveness, the more mothers can exert positive emotional control and lose anxiety; hence, it is vital that family environments should ensure that mothers are not depressed and are able to contribute to the warmth of family relationships. Early 
father involvement can be another factor in counter-acting risk conditions that might lead to later low attainment levels (Luebbe \& Bell, 2014; Kim \& Hill, 2015).

Further, all participants pledged that they would contribute more time to and increase their communication with their children. Quality time with the children is very important, so that the children would have enough time to discuss several issues, including their passions and visions. Parents could utilize several media to interact with the children, for instance is a picture storybook. Through this media, key messages on nutrition, parenting, and child behavior using an attractive, colorful and unique appearance are presented (Agustina et al., 2018). With this value, parents can support and directing the children in achieving their visions. They also vouched that they would continuously insert positive language, positive parenting, and mindful parenting into their daily lives and would try to inculcate the best characteristics in their progeny. Parenting behaviors support the emotional outcomes of children. Parenting styles work over time and across generations as important mechanisms that aid the development of competent or problematic emotional functioning (Stack et al., 2010).

At the end of the forum, all participants realized that positive language is an approach of mindful parenting that is significantly associated with adult mental health and with a child's psychosocial adjustment in early childhood and in later life. Children with language problems have complex needs and such difficulties require early and continuing intervention in the form of educational support and services (Schoon, Parsons, Rush, \& Law, 2010). From birth, children are learning and depending on parents and other caregivers in their lives to protect and care for them. The impact of parents may never be greater than during the earliest years of life when a child's brain is rapidly developing, and when mostly all of her or his experiences are created and shaped by parents and the family environment. In this period, parents help children building and refining their knowledge and skills, charting a trajectory for their health and well-being during childhood and beyond (Gadsden, Ford, \& Breiner, 2016).

All participants also concluded that language is much more than a mere tool for communication; it also forms a child's identity, both as an individual and as part of a community. A child's language heritage is a vital aspect of selfhood as a child travels through time and space (Lee, 2009; Zhang \& Slaughter-Defoe, 2009). It is proven that the linguistic production of culture involves a variety of culture-specific subject 
positions that speakers enact through language. In fact, language is the most flexible and pervasive system for the cultural production of identity (Brock-Utne, 2017).

After the discussion forum, the research team summarized the collated data into mindful parenting guidelines that were documented in the form of a mini handbook. Previously, the community has already designed a framework of educating the children in three roots, namely mastering knowledge of belief and science; implementing good attitude; and building self-independency in life. By providing the mini handbook, the parents gain a new perspective and the detail values of the framework to be implemented. Expanding the three principal values into the following detailed ten values, has broaden the parent's point of view into more visible day-by-day actions.

The guidelines encompassed 10 principle values: 1) Allah Subhanahu wa ta'ala is the one and only Lord of the universe; 2) proportional responsibilities should be assigned to children based on their ages; 3) family principles and values should be adhered to by adults and should be introduced to children; 4) children should be reasonably involved in family and social experiences; 5) parents must engage in activities with their children; 6) parents must build mindful communication with their children; 7) parents must be honest with their children; 8) parents must be able to identify attitude changes in their children; 9) each child is unique and thus children should not be compared to each other; 10) parents must express love toward their children. All 10 values were delineated in the mini handbook, which was distributed to each participating couple. The combined impetus of the discussion forum and handbook encouraged parents to continuously implement mindful parenting based on the guidelines and personal values derived from discussions of parenting experiences.

As the community is a Muslim community, among all the ten values of the guideline, the value of Allah Subhanahu wa ta'ala is the one and only Lord, is considered as the first and the utmost value for the children and all the family members. This value is inserted into the 10 items of the parental actions in applying positive language, positive parenting, and mindful parenting. Within the values implementation, children are smoothly receiving the values and processing the values into their daily life. In this way, the family environment is indicated as an essential and effective factor in delivering the first and the utmost value on children's belief of Islam. Since this value is the most crucial value for children, parent's role is also supported by deliverers who are called mubaligh and mubalighot. Each mubaligh or mubalighot responsible for children based 
on several levels of children's age, where one mubaligh or mubalighot is taking care of 5 to 10 children. The role of mubaligh and mubalighot is provided by this Muslim community and scheduled in three times a week of learning. The learning is conducted either in the learning center or at home, depends on the children's need.

An additional value stated that parents must be honest to their children is registered in item 7. This value is identified as one of the missing values that parents usually apply in their everyday life. Parents unconsciously deny this value for some circumstances. For instance, when parents must visit a doctor or go to a hospital where this is not an appropriate place for the children due to their age and health, parents usually tell the children not to come and frighten the children with untrue story of the place. Another example, parents are easily promising things unconsciously without in-depth determination. When parents go to a market and children ask to buy something, parents easily agree with the request and promise to fulfil it in another time. Unfortunately, parents deny the promise and fulfil it. Despite of saying untrue story or promising unfulfil requirements, parents are encouraged to say the truth and offer alternatives for the children's wants. In Islam, dis-honesty is an unacceptable value and there is no parenting by lying (Heyman, Luu, \& Lee, 2009). For that reason, the value of honesty should be inserted in the guideline for parents have to be conscious of every single word they say and everything they do.

Besides the additional value of item 7 , other additional value that stated parents must be able to identify attitude changes in their children, is considered. Connected to this item 8 is parents need to be acquainted to their children, since parents are the first and the closest persons for the children. Parents must immediately recognize children's changes in mood and attitudes. This value reminds parents to determine children on gender, boys or girls. The changes of attitudes or body poses are expressively identified on boys, while the changes on mood or facial expressions are emotionally showed on the girls. Early recognition on this item would help parents to guide an intervention and help children to reduce their emotion problems. By reducing the children's emotion problems, parents are preventing children from social and behavioral functioning problems (Parker, Mathis, \& Kupersmidt, 2013).

The latest value is item 10 declared that parents must express love toward their children. This value is related to item 6 stated that parents must build mindful communication with their children. It is necessary for children to know that parents 
love them, and it is showed in the parents' communication with the children. The implementation of mindfulness is proved to be effective in reducing parenting stress and increasing parental responsiveness. Mindfulness constructs parents-children interaction in the more mindful parents are, the more attuned and responsive they are to the children' s needs (Campbell, Thoburn, \& Leonard, 2017).

This community service activity for the region covered by the membership of the Muslim community center of Baitul Hasan Jagakarsa broadened the knowledge of participating parents and encouraged their use of positive language in mindful parenting. It is recommended that such interventions should be continuous and should be expanded to other areas and to different communities. If wide coverage can be achieved by such activities to encourage the use of positive language in mindful parenting, a great movement could be initiated to build and preserve positive qualities in the future generation of Indonesia.

\section{Conclusion}

The community service activity promoting the implementation of positive language in mindful parenting as a means of building positive personalities in children was conducted in the Muslim community center of Baitul Hasan Jagakarsa. The primary activity comprised an FGD for 30 participating couples who had been married between 5 and 20 years. This activity increased the participants' knowledge and awareness about inculcating the best possible characteristics in their children. The participants were reminded to be mindful in every thought, expression, and deed committed within the family environment, particularly in the presence of children, who are wonderful imitators of adult role models. Father and mother should undertake joint responsibility for the appropriate nurturing of the next generation.

This community service activity successfully engaged, discussed, summarized, concluded, and formulated authentic guided values based on the community needs. Since the concern of building the best characters on children is every parents awareness in every religion in Indonesia, this guided value is intended not only to the current community but also to different communities. It is every parents' responsibilities to keeping up the best children personalities to be preserved. Other people may enter and exit the lives of children across space and time, but parents are always their best 
teachers and the first and primary inspiration for children. The impact of parental inputs remains with individuals throughout their lives.

\section{Acknowledgments}

Our gratitude goes to the Research and Community Service Institution (LPPM) of Universitas Indraprasta PGRI that has funded and supported for the administration of the Community Service activities. Great gratitude to Mr. Aras Lapong, S.T., the leader of the Muslim community center of Baitul Hasan Jagakarsa, who had given his permission and supports for this cooperation program. Special thanks to Mrs. Etty Sabariah, M.Psi. and Mr. David Adi Prayoga who had contributed great knowledge and participation in assisting, summarizing, and guide-lining the crucial values of mindful parenting. To the entire participants, great thankfulness goes to you for this community service activities could be accomplished successfully.

\section{Author Contribution}

Amrina Rosyada and Agustina Ramadhianti conceived of the presented idea. Amrina Rosyada developed the theory and performed the computations. Amrina Rosyada and Agustina Ramadhianti verified the analytical methods. Amrina Rosyada encouraged Agustina Ramadhianti to investigate [fathers' involvement in parenting] and supervised the findings of this work. All authors discussed the results and contributed to the final manuscript.

\section{References}

Agustina, R., Lupita Sari, O., Anisfatus Sholihah, L., Rizqi, N., Octavia, L., Laras Pramesthi, I., ... Chandra Dewi Kardha, P. (2018). Development of Innovative Picture Storybooks to Empower Parents and Teachers for Early Childhood Education in Nutrition and Social-Behavior in Jakarta. ASEAN Journal of Community Engagement, 2(2), 298-315. https://doi.org/10.7454/ajce.v2i2.128

Baker, C. (2013). Fathers' and Mothers' Home Litearcy Involvement and Children's Cognitive and Social Emotional Development: Implications for Family Literacy $\begin{array}{llll}\text { Programs. Applied Developmental } & \text { Science, 17(4), }\end{array}$ 
Amrina Rosyada, Agustina Ramadhianti | ASEAN Journal of Community Engagement | Volume 3, Number 2, 2019

Ball, J. (2010). Indigenous fathers' involvement in reconstituting "circles of care." American Journal of Community Psychology, 45(1-2), 124-138. https://doi.org/10.1007/s10464-009-9293-1

Benharoon, S. Y. (2013). Building a Culture of Peace in Muslim Community in Southern Thailand through Family Communication. Procedia - Social and Behavioral Sciences, 91(2013), 522-531. https://doi.org/10.1016/j.sbspro.2013.08.450

Brock-Utne, B. (2017). Language and identity: Reflections by a cultural commuter. In B. Maryam (Ed.), Language and Globalization: An Autoethnographic Approach (pp. 132143). Routledge, Taylor and Francis Group. https://doi.org/10.4324/9781315394626

Campbell, K., Thoburn, J., \& Leonard, H. (2017). The mediating effects of stress on the relationship between mindfulness and parental responsiveness. Couple and Family $\begin{array}{llll}\text { Psychology: Research } & \text { 48 }\end{array}$ https://doi.org/10.1037/CFP0000075

Coatsworth, J. D., Duncan, L. G., Greenberg, M. T., \& Nix, R. L. (2010). Changing parent's mindfulness, child management skills and relationship quality with their youth: Results from a randomized pilot intervention trial. Journal of Child and Family Studies, 19(2), 203-217. https://doi.org/10.1007/s10826-009-9304-8

Daniel, G. R., Wang, C., \& Berthelsen, D. (2016). Early school-based parent involvement, children's self-regulated learning and academic achievement: An Australian longitudinal study. Early Childhood Research Quarterly, 36(2016), 168-177. https://doi.org/10.1016/j.ecresq.2015.12.016

Gadsden, V., Ford, M., \& Breiner, H. (2016). Parenting matters: Supporting parents of children ages 0-8. Washington DC, USA: The National Academies Press. https://www.ncbi.nlm.nih.gov/pubmed/27997088

García-Carrión, R., \& Villardón-Gallego, L. (2016). Dialogue and Interaction in Early Childhood Education: A Systematic Review. Multidisciplinary Journal of Educational Research, 6(1), 51-76. https://doi.org/10.17583/remie.2016.1919

Gini, G., Pozzoli, T., \& Hauser, M. (2011). Bullies have enhanced moral competence to judge relative to victims, but lack moral compassion. Personality and Individual Differences, 50(5), 603-608. https://doi.org/10.1016/j.paid.2010.12.002

Gouveia, M. J., Carona, C., Canavarro, M. C., \& Moreira, H. (2016). Self-Compassion and 
Dispositional Mindfulness Are Associated with Parenting Styles and Parenting Stress: the Mediating Role of Mindful Parenting. Mindfulness, 7(3), 700-712. https://doi.org/10.1007/s12671-016-0507-y

Hale, L., \& Guan, S. (2015). Screen time and sleep among school-aged children and adolescents: A systematic literature review. Sleep Medicine Reviews, 21(2015), 50-58. https://doi.org/10.1016/j.smrv.2014.07.007

Heyman, G. D., Luu, D. H., \& Lee, K. (2009). Parenting by lying. Journal of Moral Education, 38(3), 353-369. https://doi.org/10.1080/03057240903101630

IOM (Institute of Medicine). (2013). Educating the Student Body: Taking Physical Activity and Physical Education to School. The National Academies Press. https://doi.org/10.17226/18314

Kim, S., \& Hill, N. (2015). Including fathers in the picture: A meta-analysis of parental involvement and students' academic achievement. Journal of Educational Psychology, 107(4), 919-934. https://doi.org/10.1037/edu0000023

Kopala-Sibley, D. C., Jelinek, C., Kessel, E. M., Frost, A., Allmann, A. E. S., \& Klein, D. N. (2017). Parental depressive history, parenting styles, and child psychopathology over 6 years: The contribution of each parent's depressive history to the other's parenting styles. Development and Psychopathology, 29(4), 1469-1482. https://doi.org/10.1017/S0954579417000396

Lang, D., Wiek, A., Bergmann, M., Stauffacher, M., Martens, P., Moll, P., Swilling, M., \& Thomas, C. J. (2012). Transdisciplinary research sustainability science: Practice, principles, and challenges. Sustainability Science, 7(1), 25-43. https://doi.org/10.1007/s11625-011-0149-x

Lansford, J. E., Sharma, C., Malone, P. S., Woodlief, D., Dodge, K. A., Oburu, P., ... Di Giunta, L. (2014). Corporal Punishment, Maternal Warmth, and Child Adjustment: A Longitudinal Study in Eight Countries. Journal of Clinical Child and Adolescent Psychology, 43(4), 670-685. https://doi.org/10.1080/15374416.2014.893518

Larkins, C. (2014). Enacting children's citizenship: Developing understandings of how children enact themselves as citizens through actions and Acts of citizenship. Childhood, 21(1), 7-21. https://doi.org/10.1177/090756821341815

Lee, J. S. (2009). The Korean Language in America: The Role of Cultural Identity in Heritage Language Learning. Language, Culture and Curriculum, 15(2), 117-133. 


\section{https://doi.org/10.1080/07908310208666638}

Lexmond, J., \& Reeves, R. (2009). "Parents are the principal architects of a fairer society...": Building Character. Notes. London, UK. DEMOS.

Luebbe, A. M., \& Bell, D. J. (2014). Positive and negative family emotional climate differentially predict youth anxiety and depression via distinct affective pathways. Journal of Abnormal Child Psychology, 42(6), 897-911. https://doi.org/10.1007/s10802-013-9838-5

Nix, R. L., Bierman, K. L., Domitrovich, C. E., \& Gill, S. (2013). Promoting Children's SocialEmotional Skills in Preschool Can Enhance Academic and Behavioral Functioning in Kindergarten: Findings From Head Start REDI. Early Education and Development, 24(7), 1000-1019. https://doi.org/10.1080/10409289.2013.825565

Ochocka, J., \& Janzen, R. (2015). Breathing life into theory: Illustrations of communitybased research - Hallmarks, functions and phases. Gateways: International Journal of Community Research and Engagement, 7(2014), 18-33. https://doi.org/10.5130/ijcre.v7i1.3486

Parish-Morris, J., Mahajan, N., Hirsh-Pasek, K., Golinkoff, R. M., \& Collins, M. F. (2013). Once upon a time: Parent-child dialogue and storybook reading in the electronic era. Mind, Brain, and Education, 7(3), 200-211. https://doi.org/10.1111/mbe.12028

Parker, A. E., Mathis, E. T., \& Kupersmidt, J. B. (2013). How Is This Child Feeling? Preschool-Aged Children's Ability to Recognize Emotion in Faces and Body Poses. Early Education and Development, 24(2), 188-211. https://doi.org/10.1080/10409289.2012.657536

Radl, J., Salazar, L., \& Cebolla-Boado, H. (2017). Does Living in a Fatherless Household Compromise Educational Success? A Comparative Study of Cognitive and Noncognitive Skills. European Journal of Population, 33(2), 217-242. https://doi.org/10.1007/s10680-017-9414-8

Rahmatullah, A. S. (2017). Pendidikan Keluarga Seimbang yang Melekat Sebagai Basis yang Mencerahkan Anak di Era Digital. Cendekia: Journal of Education and Society, 15(2), 211-224. https://doi.org/10.21154/cendekia.v15i2.1144

Rosyada, A., \& Ramadhianti, A. (2019). Implementasi Bahan Positif dan Screen Time Management dalam Membangun Karakter Terbaik Anak. PkM Pengabdian Kepada Masyarakat, 2(2), 87-95. http://dx.doi.org/10.30998/jurnalpkm.v2i02.3059 
196

Amrina Rosyada, Agustina Ramadhianti | ASEAN Journal of Community Engagement | Volume 3, Number 2, 2019

Rosyada, A., \& Retnomurti, A. B. (2017). The Use of Positive Language on Children Education to Build Children's Positive Behaviour. Scope : Journal of English Language Teaching, 1(01), 1. https://doi.org/10.30998/scope.v1i01.868

Schoon, I., Parsons, S., Rush, R., \& Law, J. (2010). Children's Language Ability and Psychosocial Development: A 29-Year Follow-up Study. Pediatrics, 126(1), 73-80. https://doi.org/10.1542/peds.2009-3282

Seals, C. A. (2018). Positive and negative identity practices in heritage language education. International Journal of Multilingualism, 15(4), 329-348. https://doi.org/10.1080/14790718.2017.1306065

Stack, D. M., Serbin, L. A., Enns, L. N., Ruttle, P. L., \& Barrieau, L. (2010). Parental effects on children's emotional development over time and across generations. Infants and Young Children, 5(5), 1-12. https://doi.org/10.1097/IYC.0b013e3181c97606

Zhang, D., \& Slaughter-Defoe, D. T. (2009). Language attitudes and heritage language maintenance among chinese immigrant families in the usa. Language, Culture and Curriculum, 22(2), 77-93. https://doi.org/10.1080/07908310902935940 